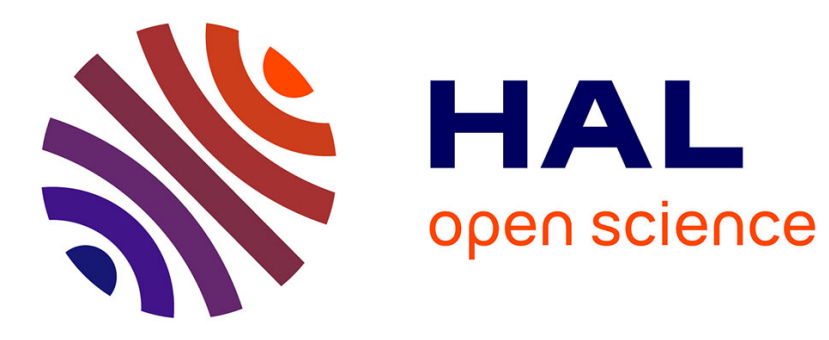

\title{
Secondary interactions - Cement in trinuclear calcium complexes
}

Sorin-Claudiu Rosca, Vincent Dorcet, Jean-François Carpentier, Yann Sarazin

\section{To cite this version:}

Sorin-Claudiu Rosca, Vincent Dorcet, Jean-François Carpentier, Yann Sarazin. Secondary interactions - Cement in trinuclear calcium complexes. Inorganica Chimica Acta, 2018, 475, pp.59-64. 10.1016/j.ica.2017.08.038 . hal-01771100

\section{HAL Id: hal-01771100 https://hal-univ-rennes1.archives-ouvertes.fr/hal-01771100}

Submitted on 26 Apr 2018

HAL is a multi-disciplinary open access archive for the deposit and dissemination of scientific research documents, whether they are published or not. The documents may come from teaching and research institutions in France or abroad, or from public or private research centers.
L'archive ouverte pluridisciplinaire HAL, est destinée au dépôt et à la diffusion de documents scientifiques de niveau recherche, publiés ou non, émanant des établissements d'enseignement et de recherche français ou étrangers, des laboratoires publics ou privés. 


\section{Secondary Interactions - Cement in Trinuclear Calcium Complexes}

Sorin-Claudiu Roşca, Vincent Dorcet, Jean-François Carpentier, Yann Sarazin*

Université de Rennes 1, CNRS, Institut des Sciences Chimiques de Rennes, UMR 6226, Campus de Beaulieu, F-35042 Rennes Cedex France

A contribution in honour of Professor Ionel Haiduc, for the celebration of his $80^{\text {th }}$ birthday 


\begin{abstract}
The trinuclear calcium complex $\left[\mathrm{Ca}_{3}\left(\mu^{2}-\left\{\mathrm{RO}^{1}\right\}\right)_{2}\left(\mu^{2}-\mathrm{N}\left(\mathrm{SiMe}_{2} \mathrm{H}\right)_{2}\right)_{2}\left(\mathrm{~N}\left(\mathrm{SiMe}_{2} \mathrm{H}\right)_{2}\right)_{2}\right]$ (2) was synthesised upon stoichiometric or substoichiometric reactions between $\left[\mathrm{Ca}\left[\mathrm{N}\left(\mathrm{SiMe}_{2} \mathrm{H}\right)_{2}\right]_{2} \bullet\right.$ (THF) $]$ and the aminofluoroalcohol $\mathrm{CH}_{2}=\mathrm{CH}-\left(\mathrm{CH}_{2}\right)_{2} \mathrm{~N}\left({ }^{\mathrm{t}} \mathrm{Bu}\right) \mathrm{CH}_{2} \mathrm{C}\left(\mathrm{CF}_{3}\right)_{2} \mathrm{OH}$, $\left\{\mathrm{RO}^{1}\right\} \mathrm{H}$. This unusual calcium cluster was characterised by X-ray diffraction crystallography. It contains bridging alkoxides and amides, and is stabilised by a remarkable pattern of intramolecular $\beta-\mathrm{Si}-\mathrm{H} \cdots \mathrm{Ca}$ agostic and $\mathrm{C}-\mathrm{F} \cdots \mathrm{Ca}$ interactions which are amongst the shortest known to date. Bond valence sum analysis showed that far from being negligible, these secondary interactions amount to about $20 \%$ of the overall bonding pattern about the calcium atoms in 2 . These results provide further evidence of the importance of non-covalent interactions in the coordination chemistry of alkaline earths, as a useful tool to design original molecular edifices.
\end{abstract}

Keywords: calcium; secondary interactions; fluoroalkoxide; agostic bonding; calcium-fluorine interactions 


\section{Introduction}

The chemistry of the large alkaline earth metals (= Ae) barium, strontium and, most prominently, calcium, is receiving increasing attention. This stems notably from the ability of Ae complexes to act as versatile molecular catalysts for a broad range of catalysed organic transformations [1], and from their unusual reactivity towards small molecules [2]. Despite these advances and other achievements in the fundamental organometallic chemistry of calcium [3], convenient access to stable Ae complexes still remains troublesome. $\mathrm{Ca}, \mathrm{Sr}$ and $\mathrm{Ba}$ are characterised by their large ionic radii (for C.N. $=6: \mathrm{Ca}^{2+}, 1.00 \AA$; $\mathrm{Sr}^{2+}, 1.18 \AA ; \mathrm{Ba}^{2+}, 1.35 \AA$ ), and their high polarisability and electropositivity. They form $d^{0}$ complexes where the bonding around the $\mathrm{Ae}^{2+}$ metal ion (the main stable oxidation state for Ae complexes is $+\mathrm{II}$, even if an exquisite case of $\mathrm{Ca}(+\mathrm{I})$ complex is known [4]) is very ionic, and with this comes the issue of kinetic lability in solution. Heteroleptic complexes of the type $\left[\{\mathrm{LX}\} \mathrm{Ae}(\mathrm{Nu}) \cdot(\text { solvent })_{n}\right]$, where $\{\mathrm{LX}\}^{-}$is a monoanionic ancillary ligand and $\mathrm{Nu}^{-}$is a reactive nucleophile, indeed often decompose in solution due to ligand redistribution processes (aka Schlenk equilibria), yielding ill-defined mixtures of homoleptic $\left[\{\mathrm{LX}\}_{2} \mathrm{Ae}\right]$ and $\left[\mathrm{Ae}(\mathrm{Nu})_{2}\right]_{x}$, and possible other complex compounds, that cannot be utilised as such in catalysis [5]. Ligand design has been optimised in the last decade to impede kinetic lability in Ae complexes. For instance, bulky nitrogen-based "nacnac" [6] and iminoanilido [7] ligands or oxygen-based phenolates [8] and fluorinated alkoxides [9] have proved very efficient. And yet, bulky multidentate ligands do not always warrant the production of kinetically inert complexes.

In 2010, Ruhlandt-Senge reviewed the importance of non-covalent, secondary interactions in alkaline earth chemistry [10]. Agostic $\mathrm{Ae} \cdots \mathrm{H}-\mathrm{X}, \mathrm{Ae} \cdots \mathrm{C} \pi$ and $\mathrm{C}-\mathrm{F} \cdots \mathrm{Ae}$ interactions were in particular mentioned as key tools for the stabilisation of otherwise unstable Ae complexes. Our group has hence endeavoured to synthesise electron-deficient Ae complexes that include 
secondary interactions as their main structural features [1e]. We have shown that $\beta-\mathrm{Si}-\mathrm{H}$ agostic (strength estimated to ca. $5 \mathrm{kcal} \mathrm{mol}^{-1}$ by DFT computations) and $\mathrm{C}-\mathrm{F} \cdots \mathrm{Ae}$ interactions (in the range $10-25 \mathrm{kcal} \mathrm{mol}^{-1}$ ) enabled the synthesis of unusual Ae complexes [11], e.g. $O$-bridged dinuclear cations $[9,12]$ and Ae-olefin [13] adducts supported by functionalised fluoroalkoxides (Fig. 1).

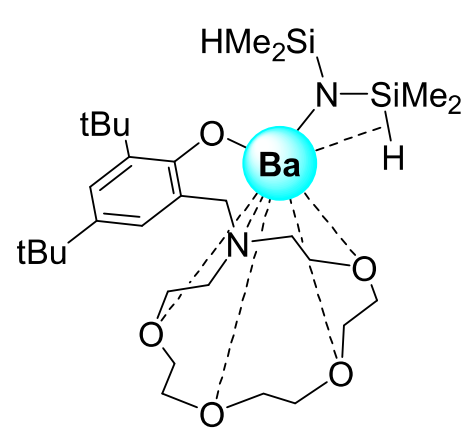

$\beta-\mathrm{Si}-\mathrm{H}-\mathrm{Ae}$ interaction [11]

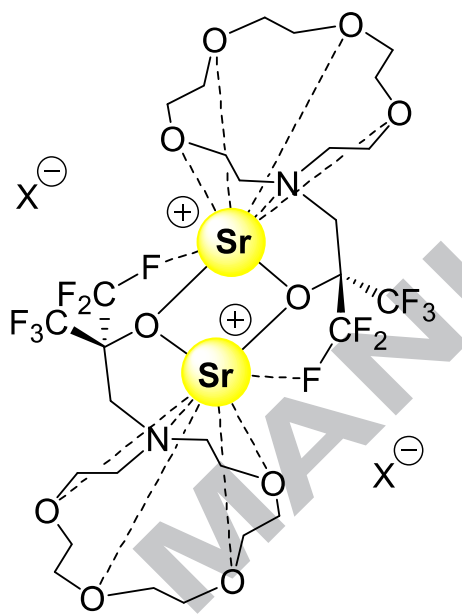

$\mathrm{C}-\mathrm{F} \rightarrow \mathrm{Ae}$ interaction [12]

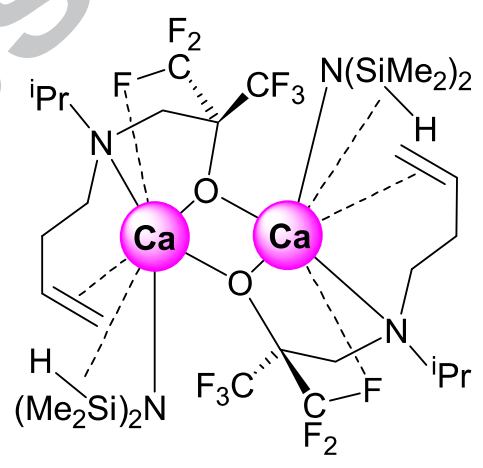

$\mathrm{Ae}-\mathrm{C} \pi$ interaction [13]

Fig. 1. Examples of alkaline-earth complexes stabilised by secondary interactions.

As part of our ongoing programme towards the design of Ae catalysts, we report here the synthesis and structural characterisation of an unusual trinuclear calcium complex that incorporate a fluoroalkoxo ligand. It follows up on our earlier report of a related trinuclear calcium complex, which resulted from our failed attempt at synthesising intramolecular Ca$\mathrm{C} \pi$ (arene) adducts [13b]. It is shown that the presence of multiple $\beta-\mathrm{Si}-\mathrm{H}$ agostic and $\mathrm{C}-\mathrm{F} \cdots \mathrm{Ca}$ interactions contribute towards the stability of these trinuclear architectures. 


\section{Results and discussion}

The fluoroalcohol $\left\{\mathrm{RO}^{1}\right\} \mathrm{H}$ containing an olefin tether was obtained in $85 \%$ yield as a colourless, analytically pure oil by reacting $N$-(tert-butyl)but-3-en-1-amine with 1,1-bis(trifluoromethane)oxirane (Fig. 2). It was fully characterised by all standard analytical techniques. Its ${ }^{19} \mathrm{~F}\left\{{ }^{1} \mathrm{H}\right\}$ NMR spectrum recorded at $25^{\circ} \mathrm{C}$ in benzene- $d_{6}$ features two unresolved quartets (appearing as broad resonances) at -77.35 and $-77.04 \mathrm{ppm}$, i.e. in the region expected for such $\mathrm{CF}_{3}$ moieties $[9,12-$ 13].

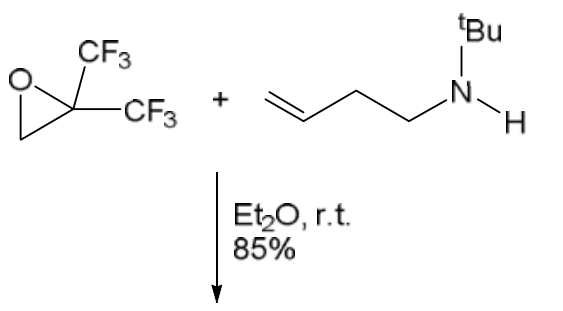<smiles>C=CCCN(CC(C)(C)C)CC(O)(C(F)(F)F)C(F)(F)F</smiles>

$\left\{\mathrm{RO}^{1}\right\} \mathrm{H}$
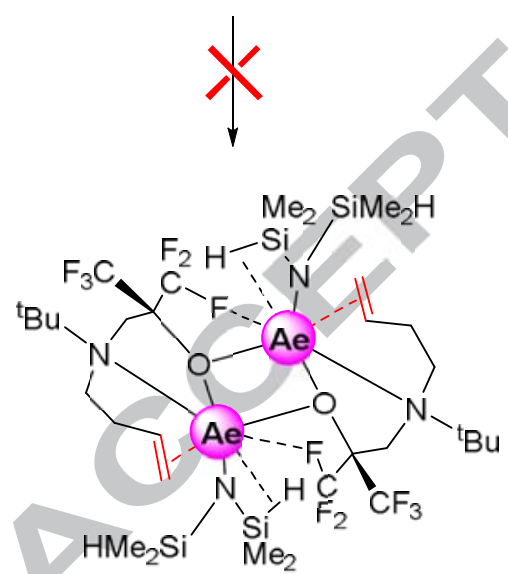

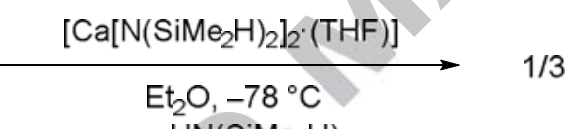
$-\mathrm{HN}\left(\mathrm{SiMe}_{2} \mathrm{H}\right)_{2}$ - THF

\section{(1)}

Fig. 2. Syntheses of $\left\{\mathrm{RO}^{1}\right\} \mathrm{H}$ and of $\left[\mathrm{Ca}_{3}\left(\mu^{2}-\left\{\mathrm{RO}^{1}\right\}\right)_{2}\left(\mu^{2}-\mathrm{N}\left(\mathrm{SiMe}_{2} \mathrm{H}\right)_{2}\right)_{2}\left(\mathrm{~N}\left(\mathrm{SiMe}_{2} \mathrm{H}\right)_{2}\right)_{2}\right](2)$.

Treatment of the calcium precursor $\left[\mathrm{Ca}\left[\mathrm{N}\left(\mathrm{SiMe}_{2} \mathrm{H}\right)_{2}\right]_{2} \bullet(\mathrm{THF})\right]$ with an equimolar amount of $\left\{\mathrm{RO}^{1}\right\} \mathrm{H}$ in $\mathrm{Et}_{2} \mathrm{O}$ at low temperature did not yield the olefin adduct $\left[\left\{\mathrm{RO}^{1}\right\} \mathrm{Ca}\left(\mu^{2}-\right.\right.$ $\left.\left.\mathrm{N}\left(\mathrm{SiMe}_{2} \mathrm{H}\right)_{2}\right]_{2}\right]_{2}(\mathbf{1})$ expected on the basis of similar reactions where the $N$-atom bore an ${ }^{\mathrm{i}} \mathrm{Pr}$ group 
in the place of the ${ }^{\mathrm{t}} \mathrm{Bu}$ group in $\left\{\mathrm{RO}^{1}\right\} \mathrm{H}$ [13]. Instead, it returned repeatedly a trinuclear cluster of overall composition $\left[\mathrm{Ca}_{3}\left(\mu^{2}-\left\{\mathrm{RO}^{1}\right\}\right)_{2}\left(\mu^{2}-\mathrm{N}\left(\mathrm{SiMe}_{2} \mathrm{H}\right)_{2}\right)_{2}\left(\mathrm{~N}\left(\mathrm{SiMe}_{2} \mathrm{H}\right)_{2}\right)_{2}\right]$ (2), established on the basis of X-ray diffraction analysis of single crystals (vide infra). Complex $\mathbf{2}$ was isolated as an extremely air-sensitive, colourless solid in a non-optimised $57 \%$ yield, based on calcium. This initial synthesis of 2 involving a 1:1 ratio of $\left[\mathrm{Ca}\left[\mathrm{N}\left(\mathrm{SiMe}_{2} \mathrm{H}\right)_{2}\right]_{2} \bullet(\mathrm{THF})\right]$ and $\left\{\mathrm{RO}^{1}\right\} \mathrm{H}$ can be optimised. The reaction with these reagents in optimal 3:2 proportions hence returned $\mathbf{2}$ in improved yield (68\%) and high purity of the crude product. It can also be prepared cleanly by stoichiometric reaction of the homoleptic complex $\left[\left\{\mathrm{RO}^{1}\right\}_{2} \mathrm{Ca}\right]$ and $\left[\mathrm{Ca}\left[\mathrm{N}\left(\mathrm{SiMe}_{2} \mathrm{H}\right)_{2}\right]_{2} \bullet(\mathrm{THF})\right]$ (1:2), although it also forms if sub-stoichiometric amounts of $\left[\mathrm{Ca}\left[\mathrm{N}\left(\mathrm{SiMe}_{2} \mathrm{H}\right)_{2}\right]_{2} \bullet(\mathrm{THF})\right](1.3$ equivalent vs. the homoleptic precursor) are used.

Unexpectedly for an oxophilic element such as calcium, 2 did not contain coordinated THF, despite the presence of one equivalent of the Lewis base per metal in the starting material $\left[\mathrm{Ca}\left[\mathrm{N}\left(\mathrm{SiMe}_{2} \mathrm{H}\right)_{2}\right]_{2} \bullet(\mathrm{THF})\right]$. Complex 2 was characterised by ${ }^{1} \mathrm{H},{ }^{13} \mathrm{C}$ and ${ }^{19} \mathrm{~F}$ NMR spectroscopy and X-ray diffraction crystallography. It is structurally very comparable to $\left[\mathrm{Ca}_{3}\left(\mu^{2}-\left\{\mathrm{RO}^{2}\right\}\right)_{2}\left(\mu^{2}-\right.\right.$ $\left.\left.\mathrm{N}\left(\mathrm{SiMe}_{2} \mathrm{H}\right)_{2}\right)_{2}\left(\mathrm{~N}\left(\mathrm{SiMe}_{2} \mathrm{H}\right)_{2}\right)_{2}\right](3)$, where the ligand $\left\{\mathrm{RO}^{2}\right\}^{-}$contains a dangling aromatic ring (instead of an olefin) and a $N$-methyl substituent (Fig. 3) [13b]. Note that although the structures of $\mathbf{2}$ and $\mathbf{3}$ are comparable, the three calcium centres in $\mathbf{3}$ are inequivalent while in $\mathbf{2}$, the two terminal calcium ions ( $\mathrm{Ca} 2$ and $\mathrm{Ca} 2$ ') are identical. 


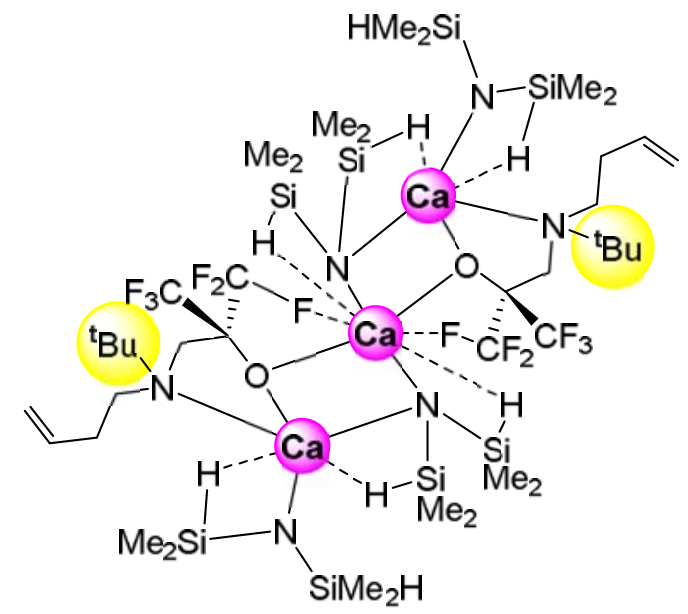

$\left[\mathrm{Ca}_{3}\left(\mu^{2}-\left\{\mathrm{RO}^{1}\right\}\right)_{2}\left(\mu^{2}-\mathrm{N}\left(\mathrm{SiMe}_{2} \mathrm{H}\right)_{2}\right)_{2}\left(\mathrm{~N}\left(\mathrm{SiMe}_{2} \mathrm{H}\right)_{2}\right)_{2}\right]$

(2, this work)

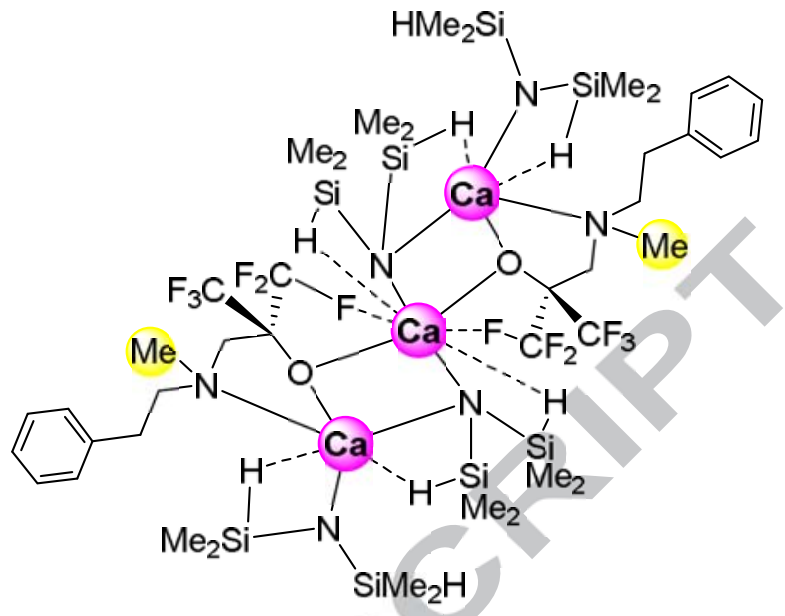

$\left[\mathrm{Ca}_{3}\left(\mu^{2}-\left\{\mathrm{RO}^{2}\right\}\right)_{2}\left(\mu^{2}-\mathrm{N}\left(\mathrm{SiMe}_{2} \mathrm{H}\right)_{2}\right)_{2}\left(\mathrm{~N}\left(\mathrm{SiMe}_{2} \mathrm{H}\right)_{2}\right)_{2}\right]$

$(3$, reference [13b])

Fig. 3. Molecular structures of $\left[\mathrm{Ca}_{3}\left(\mu^{2}-\left\{\mathrm{RO}^{\mathrm{x}}\right\}\right)_{2}\left(\mu^{2}-\mathrm{N}\left(\mathrm{SiMe}_{2} \mathrm{H}\right)_{2}\right)_{2}\left(\mathrm{~N}\left(\mathrm{SiMe}_{2} \mathrm{H}\right)_{2}\right)_{2}\right](\mathbf{2}-3)$.

The molecular solid-state structure of $\mathbf{2}$ was established by X-ray diffraction methods $\left(R_{\text {int }}\right.$ $=3.78 \%$, final $R_{1}=2.91 \%$ ). It crystallises in the Aba2 space group. In the trinuclear arrangement depicted in Fig. 4, the geometrical features about the two terminal calcium ions ( $\mathrm{Ca} 2$ and $\mathrm{Ca} 2$ ') are identical, but they differ from those about the centre calcium Ca1. A crystallographic $C_{2^{-}}$ symmetry axis goes through $\mathrm{Ca} 1$ and bisects the $\mathrm{Ca} 2-\mathrm{Ca} 1-\mathrm{Ca} 2$ ' angle. The most prominent structural features of this calcium cluster include several very short $\beta-\mathrm{Si}-\mathrm{H} \cdots \mathrm{Ca}$ agostic interactions (i.e. the electrostatic 2-electro-3-centre interactions between the calcium ions and neighbouring $\mathrm{Si}-\mathrm{H}$ moieties) and $\mathrm{C}-\mathrm{F} \cdots \mathrm{Ca}$ interactions. The $\mathrm{Ca} 1-\mathrm{H} 1, \mathrm{Ca} 2-\mathrm{H} 1$ ' and in particular Ca2-H2 distances (2.661(37), 2.573(37) and 2.37(4) $\AA$, respectively) are amongst the shortest reported to date for similar cases of agostic bonding [1e,11,13], and they are even slightly shorter than in the congeneric complex 3 (in the range 2.39(2)-2.97(2) $\AA$ ). The Ca2-H4 distance (2.994(38) ^) is longer, but still testifies to substantial agostic contact. The presence of strong agostic interactions in $\mathbf{2}$ is further evidenced by the large discrepancies between $\mathrm{Ca}-\mathrm{N}-\mathrm{Si} \mathrm{i}_{\mathrm{x}}$ angles [1e,14]: compare for instance Ca1-N1-Si1 $\left(98.97(10)^{\circ}\right)$ with the much more obtuse 
$\left.{ }^{\circ}\right)$.

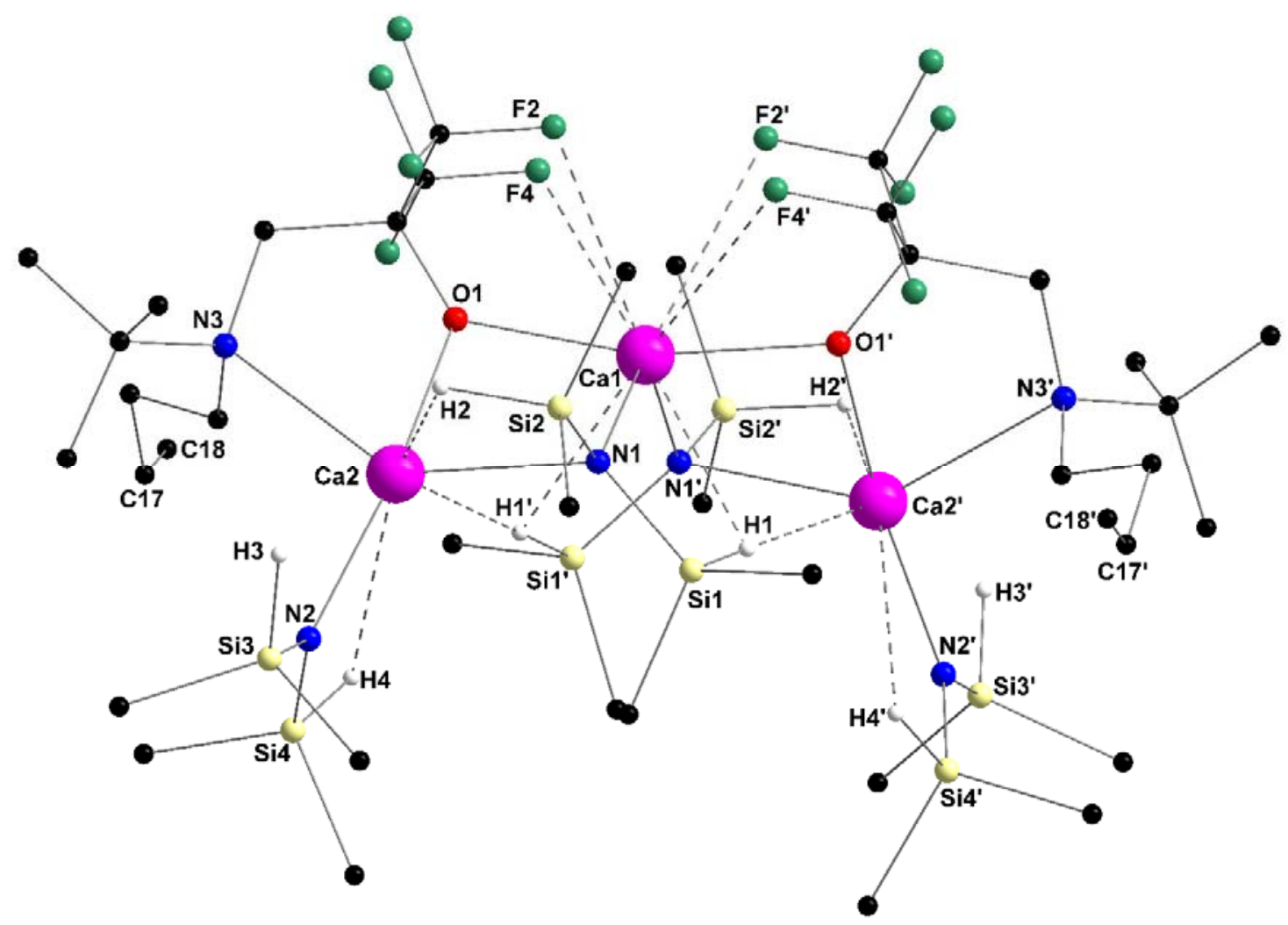

Fig. 4. Representation of the structure of $\left[\mathrm{Ca}_{3}\left(\mu^{2}-\left\{\mathrm{RO}^{1}\right\}\right)_{2}\left(\mu^{2}-\mathrm{N}\left(\mathrm{SiMe}_{2} \mathrm{H}\right)_{2}\right)_{2}\left(\mathrm{~N}\left(\mathrm{SiMe}_{2} \mathrm{H}\right)_{2}\right)_{2}\right](2) . \mathrm{H}$ atoms other than $\mathrm{SiH}$ are omitted for clarity. Secondary $\beta-\mathrm{Si}-\mathrm{H} \cdots \mathrm{Ca}$ agostic and $\mathrm{C}-\mathrm{F} \cdots \mathrm{Ca}$ interactions are depicted in dotted lines. Selected bond lengths $(\AA)$ and angles $\left({ }^{\circ}\right)$ : Ca1-O1 = 2.2873(17), $\mathrm{Ca} 1-\mathrm{N} 1=2.477(2), \mathrm{Ca} 1-\mathrm{F} 2=3.052(2), \mathrm{Ca} 1-\mathrm{F} 4=3.011(2), \mathrm{Ca} 1-\mathrm{H} 1=2.661(37)$, $\mathrm{Ca} 2-\mathrm{O} 1=2.2888(19), \mathrm{Ca} 2-\mathrm{N} 1=2.507(2), \mathrm{Ca} 2-\mathrm{N} 2=2.309(2), \mathrm{Ca} 2-\mathrm{N} 3=2.664(2), \mathrm{Ca} 2-\mathrm{H} 1{ }^{\prime}=$ 2.573(37), Ca2-H2 = 2.37(4), Ca2-H4 = 2.994(38); Ca1-N1-Si1 = 98.97(10), Ca1-N1-Si2 = 127.41(11), Ca2-N2-Si3 = 121.53(12), Ca2-N2-Si4 = 111.40(12). 
The four $\mathrm{C}-\mathrm{F} \cdots \mathrm{Ca}$ interactions involve the central calcium centre $\mathrm{Ca}$ 1. They are typical of this type of interactions, and the pertaining $\mathrm{Ca} 1-\mathrm{F}_{\mathrm{x}}$ distances (in the range 3.052(2)-3.011(2) $\AA$ ) are below the commonly accepted distance $(3.13 \AA$ ) for significant interactions between these two elements [15]. Note that the four Ca1- $\mathrm{F}_{\mathrm{x}}$ contacts in $\mathbf{2}$ are not as strong as those of the three analogous interactions in 3 (between 2.740(1) and 3.080(1) $\AA$ ); this undoubtedly results from the greater number of the contacts in $\mathbf{2}$. The distance for the external calcium centres $\mathrm{Ca} 2$ and $\mathrm{Ca} 2$ ' to the terminal amides $(\mathrm{Ca} 2-\mathrm{N} 2=2.309(2) \AA)$ are much shorter than those to the bridging amides $(\mathrm{Ca} 2-\mathrm{N} 1=2.507(2) \AA)$. On the other hand, the bond lengths between the bridging $\mu^{2}-N_{\text {amide }}$ atoms and the central $(\mathrm{Ca} 1-\mathrm{N} 1=2.477(2) \AA)$ and terminal calcium ions $(\mathrm{Ca} 2-\mathrm{N} 1=2.507(2) \AA)$ are comparable, despite the very different coordination spheres around $\mathrm{Ca} 1$ and $\mathrm{Ca} 2$. We note that the coordinated $N_{\text {amine }}$ atoms are located even further from Ca2 and Ca2' $(\mathrm{Ca} 2-\mathrm{N} 3=2.664(2)$ $\AA$ ). Surprisingly, the bridging $\mu^{2}-O_{\text {alkoxide }}$ atoms are equidistant from the central and terminal calcium centres, compare $\mathrm{Ca} 1-\mathrm{O} 1=2.287(2)$ with $\mathrm{Ca} 2-\mathrm{O} 1=2.289(2) \AA$. Finally, unlike in other calcium complexes supported by olefin-functionalised fluoroalkoxides [13], the olefins tether are dissociated from the metals in $\mathbf{2}$, with distances between $\mathrm{Ca} 2$ and the unsaturated carbon atoms C17 (5.218(3) A) and C18 (6.152(3) $\AA$ ) much too long for any type of $\pi$ interaction. Therefore, with the $\beta-\mathrm{Si}-\mathrm{H} \cdots \mathrm{Ca}$ agostic and $\mathrm{C}-\mathrm{F} \cdots \mathrm{Ca}$ interactions into account, $\mathrm{Ca} 1$ and $\mathrm{Ca} 2$ are respectively 10 - and 7-coordinated.

The NMR data of crystalline 2 recorded at room or low temperatures in benzene- $d_{6}$ or toluene- $d_{8}$ proved little informative. The ${ }^{19} \mathrm{~F}$ NMR spectrum exhibits two broad resonances (presumably unresolved quartets) at -78.15 and $-78.95 \mathrm{ppm}$. The ${ }^{1} \mathrm{H}$ NMR spectrum in benzene$d_{6}$ featured multiple resonances, and detailed assignment proved impossible due to the extreme complexity of the structure of the complex. It however clearly testifies to the presence of at least 
five different types of $\mathrm{SiH}$ hydrogens, as evidenced by the multiple overlapping resonances in the region between 4.5 and $5.5 \mathrm{ppm}$ diagnostic of these fragments. This is corroborated by the complexity of the pattern in the region $0-0.75 \mathrm{ppm}$, where $\mathrm{Si}\left(\mathrm{CH}_{3}\right)_{2}$ are expected to be found. The resonances for $\mathrm{CH}=\mathrm{CH}_{2}$ hydrogens appear as a multiplet centred on $5.65 \mathrm{ppm}$, while the terminal vinylic $\mathrm{CH}=\mathrm{CH}_{2}$ hydrogens give rise to a resonance at ca. $5.04 \mathrm{ppm}$ that overlaps with resonances for $\mathrm{SiH}$ hydrogens. In the ${ }^{13} \mathrm{C}\left\{{ }^{1} \mathrm{H}\right\}$ NMR spectrum, the major resonances for $\mathrm{CH}=\mathrm{CH}_{2}$ and $\mathrm{CH}=\mathrm{CH}_{2}$ are located at 134.26 and $117.94 \mathrm{ppm}$, respectively. $\mathrm{A}$ second set of minor resonances belonging to an isomer, the origin of which could not be elucidated, was detected at 134.61 and $117.76 \mathrm{ppm}$. The resonance for the $\mathrm{CF}_{3}$ carbon is a quartet centred on $128.59 \mathrm{ppm}$ $\left({ }^{1} J_{\mathrm{CF}}=285.8 \mathrm{~Hz}\right)$, while a multiplet of very weak intensity at $79.58 \mathrm{ppm}$ was assigned to $C\left(\mathrm{CF}_{3}\right)_{2}$. The structure of $\mathbf{2}$ is maintained in solution in benzene- $d_{6}$, as suggested by DOSY NMR spectroscopy. Comparison of the hydrodynamic radii established by XRD analysis for the trinuclear complex $\left(r_{\mathrm{XRD}}=6.24 \AA\right)$ and DOSY NMR $\left(r_{\mathrm{DOSY}}=7.93 \AA\right)$ were comparable [16]; we are however aware that the shape of the trinuclear species deviates substantially from the ideal spherical shape for such analysis. Finally, the ${ }^{1} \mathrm{H}-{ }^{29} \mathrm{Si}$ gHMQC spectrum of 2 was recorded in benzene- $d_{6}$ at $25{ }^{\circ} \mathrm{C}$. It shows the presence of at least six different ${ }^{1} J_{1 \mathrm{H}-29 \mathrm{Si}}$ coupling constants. Four are typical of mild $\beta-\mathrm{Si}-\mathrm{H} \cdots \mathrm{Ca}$ agostic interactions $(160,161,161$ and $164 \mathrm{~Hz})$, one testifies to a strong interaction $(146 \mathrm{~Hz})$, and one in particular is diagnostic of a very intense interaction $(133 \mathrm{~Hz})$. The multiplicity of these coupling constants for different $\mathrm{Si}-\mathrm{H}$ moieties is another evidence that $\mathbf{2}$ maintains its intricate structure in solution, or at least that it is organised in a way such that several distinct types of $\mathrm{SiH}$ moieties exist.

The contributions of $\beta-\mathrm{Si}-\mathrm{H}$ agostic and $\mathrm{C}-\mathrm{F} \cdots \mathrm{Ca}$ secondary interactions towards the coordination sphere of the metal ions in $\mathbf{2}$ were gauged using Bond Valence Sum (BVS) analysis. 
This model, first introduced by Brown and Altermatt [17] and further developed by O'Keefe and Brese [18], makes use of bond distances determined by single-crystal X-ray diffraction to assign the contribution of each neighbouring atom towards the metallic centre through traditional interactions and secondary interactions. It has been used abundantly in recent years to analyse the bonding patterns of many group 1 and group 2 complexes, in particular with respect to noncovalent interactions [19]. Bond valences (v) were calculated for $\mathrm{Ca} 1$ and $\mathrm{Ca} 2$ in complex 2 using eq 1 , with experimental bond lengths $d_{\text {Met-X }}$ and tabulated bond lengths $R_{\text {Met-X: }}$

$v=\exp \left[\left(R_{\mathrm{Ca}-\mathrm{X}}-d_{\mathrm{Ca}-\mathrm{X}}\right) / \mathrm{B}\right]$

where $\mathrm{X}=\mathrm{O}, \mathrm{F}, \mathrm{N}, \mathrm{H} ; \mathrm{B}=0.37 ; R_{\mathrm{Ca}-\mathrm{O}}=1.967, R_{\mathrm{Ca}-\mathrm{F}}=1.842, R_{\mathrm{Ca}-\mathrm{N}}=2.140$, and $R_{\mathrm{Ca}-\mathrm{H}}=1.830$ [17,18]. Coordinative saturation about the calcium centres $\mathrm{Ca} 1$ and $\mathrm{Ca} 2$ (and $\mathrm{Ca} 2$ ') in $\mathbf{2}$ is not achieved if only coordination of the $N$ and $O$ atoms is considered (Table 1). By contrast, the inclusion of $\mathrm{C}-\mathrm{F} \cdots \mathrm{Ca}$ and $\beta-\mathrm{Si}-\mathrm{H} \cdots \mathrm{Ca}$ interactions affords near coordinative saturation. For each $\mathrm{Ca}^{2+}$ ion, the empirical sum of the individual contributions is very close to their theoretical value of 2, with $\Sigma\left(v_{\mathrm{Ca}-\mathrm{x}}\right)$ reaching 2.018 and 2.075 for $\mathrm{Ca} 1$ and $\mathrm{Ca} 2 / \mathrm{Ca} 2$ ', respectively. For the central $\mathrm{Ca}$, the contributions of $\mathrm{C}-\mathrm{F} \cdots \mathrm{Ca}$ contacts to the bonding pattern amount to $8 \%$, while it is even greater, $10 \%$, for the agostic $\beta-\mathrm{Si}-\mathrm{H} \cdots \mathrm{Ca}$ interactions. The contributions of $\beta-\mathrm{Si}-\mathrm{H} \cdots \mathrm{Ca}$ agostic bonding to the coordination spheres of $\mathrm{Ca} 2$ and $\mathrm{Ca} 2$ ' comes to an amazing $20 \%$, and are commensurate with the contributions of $O_{\text {alkoxide }}$ atoms (O1 and $\mathrm{O} 1$ '). The total contribution of C-F - Ca to the bonding pattern around $\mathrm{Ca} 1$ is for instance twice as great as that evaluated for an aminoether fluoroalkoxide $O$-bridged dinuclear complex (4\%, [9]). Although the contributions of $\mathrm{C}-\mathrm{F} \cdots \mathrm{Ca}$ and $\beta-\mathrm{Si}-\mathrm{H} \cdots \mathrm{Ca}$ interactions with respect to $\mathrm{Ca}-\mathrm{O}$ and $\mathrm{Ca}-\mathrm{N}$ bonds should be considered in a qualitative manner, there can be no doubt that they hold a great influence of the formation of $\mathbf{2}$, and in the overall stability of this unusual trinuclear calcium edifice. The 
structural and BVS data collated for complex 2 hence constitute another addition to the growing body of information that testify to the primary importance of long overlooked secondary interactions in the coordination chemistry of $s$-block metals $[9-14,19,20]$.

Table 1

Bond Valence Sum analysis for $\left[\mathrm{Ca}_{3}\left(\mu^{2}-\left\{\mathrm{RO}^{1}\right\}\right)_{2}\left(\mu^{2}-\mathrm{N}\left(\mathrm{SiMe}_{2} \mathrm{H}\right)_{2}\right)_{2}\left(\mathrm{~N}\left(\mathrm{SiMe}_{2} \mathrm{H}\right)_{2}\right)_{2}\right](2)$

\begin{tabular}{|c|c|c|c|c|c|c|c|c|c|c|}
\hline & & $d_{\mathrm{Ca}-\mathrm{O}}^{\mathrm{a}, \mathrm{b}}$ & $d_{\mathrm{Ca}-\mathrm{N}}^{\mathrm{a}, \mathrm{c}}$ & $d_{\mathrm{Ca}-\mathrm{F}}^{\mathrm{a}, \mathrm{d}}$ & $d_{\mathrm{Ca}-\mathrm{H}}^{\mathrm{a}, \mathrm{e}}$ & $v_{\mathrm{Ca}-\mathrm{O}} \mathrm{b,f}$ & $v_{\mathrm{Ca}-\mathrm{N}}^{\mathrm{c}, \mathrm{f}}$ & $\mathrm{v}_{\mathrm{Ca}-\mathrm{F}} \mathrm{d}, \mathrm{f}$ & $v_{\mathrm{Ca}-\mathrm{H}} \mathrm{e,f}$ & $\left(v_{C a-X}\right)^{g}$ \\
\hline \multirow[t]{4}{*}{ Ca1 } & & 2.2873 & 2.477 & 3.052 & 2.661 & 0.421 & 0.402 & 0.038 & 0.106 & \\
\hline & & & & 3.011 & & & & 0.042 & & \\
\hline & $\Sigma\left(v_{\mathrm{Ca} 1-\mathrm{X}}\right)^{\mathrm{h}}$ & & & & & 0.842 & 0.804 & 0.160 & 0.212 & 2.018 \\
\hline & $\%\left(v_{\mathrm{Ca} 1-\mathrm{X}}\right)$ & & & & & $42 \%$ & & $8 \%$ & $10 \%$ & $100 \%$ \\
\hline \multirow{3}{*}{\multicolumn{2}{|c|}{$\mathrm{Ca} 2$}} & 2.2888 & 2.507 & $\mathrm{n} / \mathrm{a}$ & 2.573 & 0.419 & 0.371 & $\mathrm{n} / \mathrm{a}$ & 0.134 & \\
\hline & & & 2.309 & & 2.37 & & 0.633 & $\mathrm{n} / \mathrm{a}$ & 0.232 & \\
\hline & & & 2.664 & & 2.994 & & 0.243 & $\mathrm{n} / \mathrm{a}$ & 0.043 & \\
\hline & $\Sigma\left(v_{\mathrm{Ca} 2-\mathrm{X}}\right)$ & & & & & 0.419 & 1.247 & 0 & 0.409 & 2.075 \\
\hline & $\%\left(\mathrm{U}_{\mathrm{Ca} 2-\mathrm{X}}\right)$ & & & & & $20 \%$ & $60 \%$ & 0 & $20 \%$ & $100 \%$ \\
\hline
\end{tabular}

${ }^{\mathrm{a}}$ Bond distances given in $\AA$, see Fig. 4 for detail. ${ }^{\mathrm{b}}$ Corresponding to Ca1-O1 and Ca2-O1. ${ }^{\mathrm{c}}$ Corresponding to Ca1-N1, Ca2-N1, Ca2-N2 and Ca2-N3. ${ }^{\mathrm{d}}$ Corresponding to Ca1-F2 and Ca1-F4. ${ }^{\mathrm{e}}$ Corresponding to Ca1-H1, Ca1-H1', Ca2-H2 and Ca2-H4. ${ }^{\mathrm{f}}$ Bond valence contribution for atom X. ${ }^{\mathrm{g}}$ Sum of all contributions for the different atoms: $\mathrm{X}=\mathrm{O}, \mathrm{N}, \mathrm{F}, \mathrm{H} .{ }^{\mathrm{h}}$ $\Sigma\left(v_{\mathrm{Ca} 1-\mathrm{X})}=2 \times v_{\mathrm{Ca} 1-\mathrm{X}}\right.$ due to $C_{2}$-symmetry about Ca1 in complex 2 .

We endeavoured to gauge the role of steric bulk in the formation of $\mathbf{2}$ and related trinuclear complexes such as 3. Dinuclear, $O$-bridged Ca-olefin complexes could be made readily when a ligand incorporating a $\mathrm{CH}=\mathrm{CH}_{2}$ olefinic side-arm instead of the aryl ring in $\left\{\mathrm{RO}^{2}\right\}^{-}[13 \mathrm{~b}]$. We initially assumed that the inability to obtain a similar dimer with $\left\{\mathrm{RO}^{2}\right\}^{-}$and the preferred formation of 3 resulted from the bulky nature of the $\mathrm{C}_{6} \mathrm{H}_{5}$ fragment. However, the present clean production of $\mathbf{2}$ and impossibility to synthesise a dinuclear Ca-olefin complex with $\left\{\mathrm{RO}^{1}\right\}^{-}$ proves our initial assumption was erroneous. Perhaps the explanation is to be found instead, or 
also, in the identity of the $N$-bound alkyl group: tert-butyl in $\left\{\mathrm{RO}^{1}\right\}^{-}$and methyl in $\left\{\mathrm{RO}^{2}\right\}^{-}$. We had already observed that the presence of a bulky group on the $N_{\text {amine }}$ atom in these ancillary amino-fluoroalkoxides could help enforce the coordination of the olefin onto the metal centre to the detriment of THF coordination.

In an attempt to similarly enforce the binding of an aromatic moiety, we modified $\left\{\mathrm{RO}^{2}\right\} \mathrm{H}$ by introducing an isopropyl group onto $N_{\text {amine }}$ in the proteo-ligand $\left\{\mathrm{RO}^{3}\right\} \mathrm{H}$. However, its reaction with $\left[\mathrm{Ca}\left[\mathrm{N}\left(\mathrm{SiMe}_{2} \mathrm{H}\right)_{2}\right]_{2} \bullet\right.$ (THF) $]$ only afforded a complex assumed to be the trinuclear $\left[\mathrm{Ca}_{3}\left(\mu^{2}-\left\{\mathrm{RO}^{3}\right\}\right)_{2}\left(\mu^{2}-\mathrm{N}\left(\mathrm{SiMe}_{2} \mathrm{H}\right)_{2}\right)_{2}\left(\mathrm{~N}\left(\mathrm{SiMe}_{2} \mathrm{H}\right)_{2}\right)_{2}\right]$ (4) on the basis of $\mathrm{X}$-ray diffraction crystallography (vide infra, Fig. 5). The NMR data for this compound were complicated due in particular to fluxionality and multiple resonances in key regions of the ${ }^{1} \mathrm{H}$ and ${ }^{19} \mathrm{~F}$ NMR spectra, which precluded assignment. XRD analysis of a small crop of single crystals revealed the molecular structure of $\left[\mathrm{Ca}_{3}\left(\mu^{2}-\left\{\mathrm{RO}^{3}\right\}\right)_{2}\left(\mu^{2}-\mathrm{N}\left(\mathrm{SiMe}_{2} \mathrm{H}\right)_{2}\right)_{2}\left(\mathrm{~N}\left(\mathrm{SiMe}_{2} \mathrm{H}\right)_{2}\right)_{2}\right](4)$. It resembles closely that of its congeners $\mathbf{2}$ and $\mathbf{3}$, but the low qualities of the data set $\left(R_{\mathrm{int}}=20.3 \%\right)$ and refinement (final $R_{1}=8.31 \%$ ) prohibit any detailed discussion of geometric parameters. The existence of a pattern of stabilising $\mathrm{C}-\mathrm{F} \cdots \mathrm{Ca}$ interactions around the central calcium $\mathrm{Ca} 2$ and $\beta-\mathrm{Si}-\mathrm{H} \cdots \mathrm{Ca}$ agostic contacts can still be established beyond doubt, while it is apparent that the aromatic rings do not bind to calcium. Of particular interest, only two $\mathrm{C}-\mathrm{F} \cdots \mathrm{Ca} 2$ interactions are detected $(\mathrm{Ca} 2-$ F22 and Ca2-F52 are around 2.745(4) and 2.786(4) A, respectively), and they seem much shorter than those in $\mathbf{2}$ which contains four such interactions about the central metal. The number and strength of $\beta-\mathrm{Si}-\mathrm{H} \cdots \mathrm{Ca}$ interactions in 4 (three around $\mathrm{Ca} 1$, around 2.51(6)-2.72(6) $\AA$; two around $\mathrm{Ca} 2$, in the range 2.57(6)-2.61(5) $\AA$; three about Ca3, between 2.46(6) and 2.75(5) $\AA$ ) are comparable with those measured in $\mathbf{2}$. 

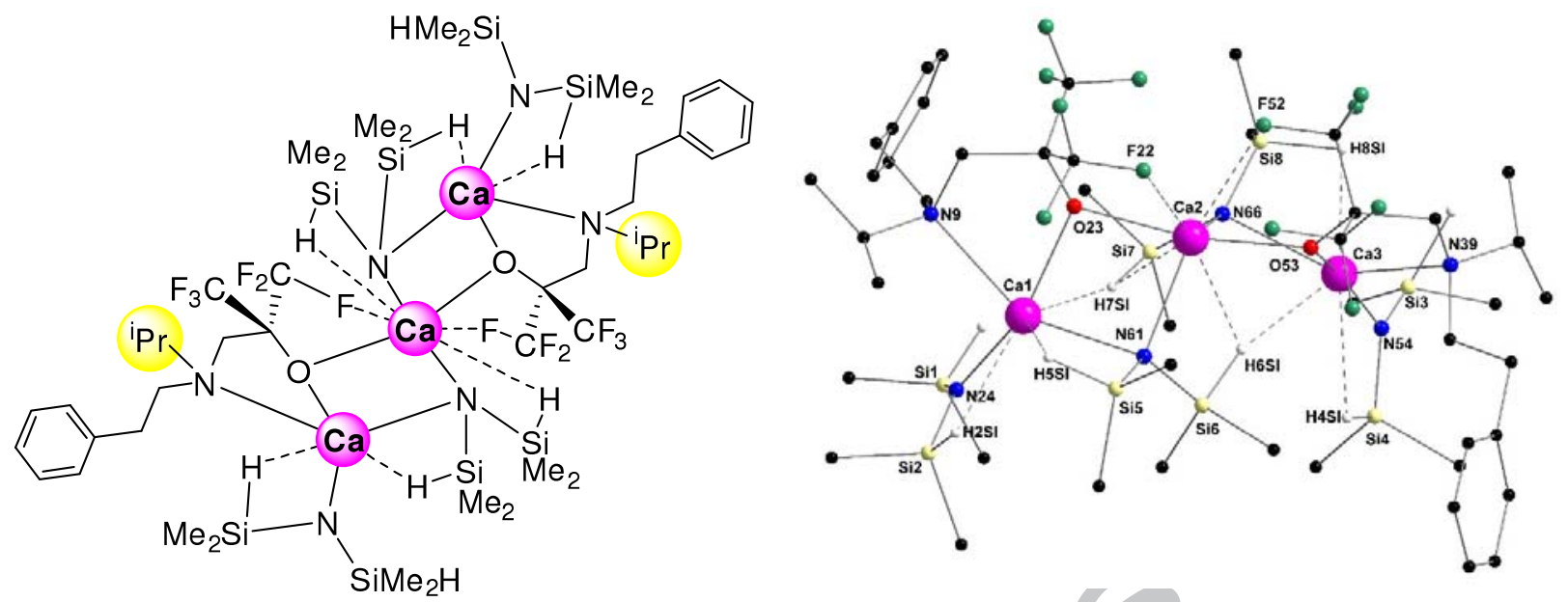

Fig. 5. Representation of the molecular solid-state structure of $\left[\mathrm{Ca}_{3}\left(\mu^{2}-\left\{\mathrm{RO}^{3}\right\}\right)_{2}\left(\mu^{2}-\right.\right.$ $\left.\left.\mathrm{N}\left(\mathrm{SiMe}_{2} \mathrm{H}\right)_{2}\right)_{2}\left(\mathrm{~N}\left(\mathrm{SiMe}_{2} \mathrm{H}\right)_{2}\right)_{2}\right](4) . \mathrm{H}$ atoms other than $\mathrm{SiH}$ are omitted for clarity. Secondary $\beta$ $\mathrm{Si}-\mathrm{H} \cdots \mathrm{Ca}$ agostic and $\mathrm{C}-\mathrm{F} \cdots \mathrm{Ca}$ interactions are depicted in dotted lines.

\section{Conclusions}

The reaction of 1 or 1.5 equivalent of the bulky olefin-functionalised fluoroalcohol $\left\{\mathrm{RO}^{1}\right\} \mathrm{H}$ with $\left[\mathrm{Ca}\left[\mathrm{N}\left(\mathrm{SiMe}_{2} \mathrm{H}\right)_{2}\right]_{2} \bullet(\mathrm{THF})\right]$ does not afford the initially expected $O$-bridged dinuclear complex $\left[\left\{\mathrm{RO}^{1}\right\} \mathrm{Ca}\left(\mu^{2}-\mathrm{N}\left(\mathrm{SiMe}_{2} \mathrm{H}\right)_{2}\right]_{2}\right]$, but instead yields a very rare case of trinuclear compound with the composition $\left[\mathrm{Ca}_{3}\left(\mu^{2}-\left\{\mathrm{RO}^{1}\right\}\right)_{2}\left(\mu^{2}-\mathrm{N}\left(\mathrm{SiMe}_{2} \mathrm{H}\right)_{2}\right)_{2}\left(\mathrm{~N}\left(\mathrm{SiMe}_{2} \mathrm{H}\right)_{2}\right)_{2}\right]$ (2). This complex owes its remarkable structure and stability to the presence of intramolecular, non-covalent $\beta-\mathrm{Si}-\mathrm{H} \cdots \mathrm{Ca}$ agostic and $\mathrm{C}-\mathrm{F} \cdots \mathrm{Ca}$ interactions, which range amongst the most intense reported to date for calcium complexes. BVS analysis evidenced that these secondary interactions constitute up to $20 \%$ of the overall bonding pattern around the $\mathrm{Ca}^{2+}$ ions in the trinuclear structure. Far from being negligible, these secondary interactions instead constitute a convenient lever for the syntheses of unusual main group metal architectures. We will continue to exploit the concept of secondary interactions in alkaline earth chemistry to devise complexes that feature unusual 
structural and reactivity features, with the longer term ambition to implement them as molecular catalysts for homogeneous catalysis.

\section{Experimental section}

\subsection{General procedures}

All manipulations were performed under inert atmosphere using standard Schlenk techniques or in a dry, solvent-free glove-box (Jacomex; $\mathrm{O}_{2}<1 \mathrm{ppm}, \mathrm{H}_{2} \mathrm{O}<5 \mathrm{ppm}$ ) for catalyst loading. $\mathrm{CaI}_{2}$ (Aldrich, 99.999\% anhydrous beads) and 2,2-bis(trifluoromethyl)oxirane (Apollo Scientific), were used as received. $\mathrm{HN}\left(\mathrm{SiMe}_{2} \mathrm{H}\right)_{2}(\mathrm{ABCR})$ was dried over $\mathrm{CaH}_{2}$ and distilled prior to use. $\left[\mathrm{Ca}\left[\mathrm{N}\left(\mathrm{SiMe}_{2} \mathrm{H}\right)_{2}\right]_{2} \bullet(\mathrm{THF})\right]$ was prepared following the literature protocol [11]. Solvents (THF, $\mathrm{Et}_{2} \mathrm{O}, \mathrm{CH}_{2} \mathrm{Cl}_{2}$, pentane and toluene) were purified and dried (water contents all below $10 \mathrm{ppm}$ ) over alumina columns (MBraun SPS). THF was further distilled under argon from sodium mirror/benzophenone ketyl. All deuterated solvents (Eurisotop, Saclay, France) were stored in sealed ampoules over activated $3 \AA$ molecular sieves and were thoroughly degassed by several freeze-thaw-vacuum cycles.

NMR spectra were recorded on a Bruker spectrometer Avance III $400 \mathrm{MHz}$ equipped with a BBOF pulsed field-gradient probe or a Bruker spectrometer Avance $500 \mathrm{MHz}$ equipped with a dual pulse field gradient probe head. All ${ }^{1} \mathrm{H}$ and ${ }^{13} \mathrm{C}$ chemicals shifts were determined using residual signals of the deuterated solvents and were calibrated vs. $\operatorname{SiMe}_{4} \cdot{ }^{19} \mathrm{~F}\left\{{ }^{1} \mathrm{H}\right\}$ chemical shifts were determined by external reference to an aqueous solution of $\mathrm{NaBF}_{4}$. Assignment of the signals was carried out using $1 \mathrm{D}\left({ }^{1} \mathrm{H},{ }^{13} \mathrm{C}\left\{{ }^{1} \mathrm{H}\right\}\right)$ and 2D (COSY, edited HSQC and HMBC) NMR experiments. 
Elemental analyses were performed on a Carlo Erba 1108 Elemental Analyzer instrument at the London Metropolitan University by Stephen Boyer and were the average of two independent measurements. ESI mass spectra were recorded on a Bruker MicrOTOF-Q II spectrometer with a QqoaTOF geometry.

\subsection{Syntheses and characterisation}

$\left\{\boldsymbol{R} \boldsymbol{O}^{\boldsymbol{I}}\right\} \boldsymbol{H}$. 2,2-Bis(trifluoromethyl)oxirane (1.39 g, $7.72 \mathrm{mmol}$ ) was added via syringe to a solution of $N$-(tert-butyl)but-3-en-1-amine $(0.82 \mathrm{~g}, 6.44 \mathrm{mmol})$ in $\mathrm{Et}_{2} \mathrm{O}(5 \mathrm{ml})$. The reaction mixture was stirred at room temperature for two days. Removal of the volatiles in vacuo yielded $\left\{\mathrm{RO}^{1}\right\} \mathrm{H}$ as a colourless oil. Yield $1.68 \mathrm{~g}(85 \%) .{ }^{1} \mathrm{H}$ NMR (benzene- $\left.d_{6}, 400.13 \mathrm{MHz}, 298 \mathrm{~K}\right): 6.48$ (s, $1 \mathrm{H}, \mathrm{OH}$ ), $5.48\left(\mathrm{ddt}, 1 \mathrm{H},{ }^{3} J_{\mathrm{H}-\mathrm{H}}(\right.$ trans $)=17.7 \mathrm{~Hz},{ }^{3} J_{\mathrm{H}-\mathrm{H}}($ cis $\left.)=9.7 \mathrm{~Hz},{ }^{3} J_{\mathrm{H}-\mathrm{H}}=6.6 \mathrm{~Hz}, \mathrm{CH}=\mathrm{CH}_{2}\right), 4.97-4.90$ (m, $2 \mathrm{H}, \mathrm{CH}=\mathrm{CH}_{2}$ ), 3.22-1.62 (overlapping m, 6H, $\mathrm{CH}_{2} \mathrm{C}\left(\mathrm{CF}_{3}\right)_{2}, \mathrm{NCH}_{2} \mathrm{CH}_{2}$ and $\mathrm{NCH}_{2} \mathrm{CH}_{2}$ ), 0.69 (s, 9H, $\left.\mathrm{C}\left(\mathrm{CH}_{3}\right)_{3}\right)$ ppm. ${ }^{13} \mathrm{C}\left\{{ }^{1} \mathrm{H}\right\}$ NMR (benzene- $\left.d_{6}, 100.62 \mathrm{MHz}, 298 \mathrm{~K}\right): \delta 135.19\left(\mathrm{CH}=\mathrm{CH}_{2}\right)$, $124.62\left(\mathrm{q},{ }^{1} J_{\mathrm{C}-\mathrm{F}}=285.1 \mathrm{~Hz}, C \mathrm{~F}_{3}\right), 116.42\left(\mathrm{CH}=C \mathrm{H}_{2}\right), 72.04\left(\mathrm{hept},{ }^{2} J_{\mathrm{C}-\mathrm{F}}=28.9 \mathrm{~Hz}, C\left(\mathrm{CF}_{3}\right)_{2}\right)$, $57.11\left(C\left(\mathrm{CH}_{3}\right)_{3}\right), 53.53\left(\mathrm{NCH}_{2} \mathrm{CH}_{2}\right), 50.35\left(\mathrm{CH}_{2} \mathrm{C}\left(\mathrm{CF}_{3}\right)_{2}\right), 27.38\left(\mathrm{C}_{\left.\left(\mathrm{CH}_{3}\right)_{3}\right) \mathrm{ppm} .}{ }^{19} \mathrm{~F}\left\{{ }^{1} \mathrm{H}\right\} \mathrm{NMR}\right.$ (benzene- $d_{6}, 376.44 \mathrm{MHz}, 298 \mathrm{~K}$ ): -76.35 (br s, 3F, $\mathrm{CF}_{3}$ ), -77.04 (br s, 3F, $\mathrm{CF}_{3}$ ) ppm. Elemental analysis for $\mathrm{C}_{12} \mathrm{H}_{19} \mathrm{~F}_{6} \mathrm{NO}\left(307.28 \mathrm{~g} \cdot \mathrm{mol}^{-1}\right)$ : calcd, C $46.9 \%, \mathrm{H} 6.2 \%, \mathrm{~N} 4.6 \%$; found $\mathrm{C} 46.8 \%, \mathrm{H}$ 6.2\%, $\mathrm{N} 4.4 \%$. Mass spectrometry ESI $\left[\mathrm{M}+\mathrm{Na}^{+}\right]\left(\mathrm{C}_{12} \mathrm{H}_{19} \mathrm{~F}_{6} \mathrm{NONa}\right) \mathrm{m} / z$ calcd: 330.1263 ; found 330.1262 .

$\left\{\boldsymbol{R} \boldsymbol{O}^{3}\right\} \boldsymbol{H}$. 2,2- bis(trifluoromethyl)oxirane $(1.13 \mathrm{~g}, 6.13 \mathrm{mmol})$ was added via syringe to a solution of $\mathrm{N}$-phenethylpropan-2-amine $(0.87 \mathrm{~g}, 5.33 \mathrm{mmol})$ in $\mathrm{Et}_{2} \mathrm{O}(5 \mathrm{ml})$. The reaction mixture was stirred at room temperature for two days. Removal of the volatiles in vacuo yielded $\left\{\mathrm{RO}^{1}\right\} \mathrm{H}$ as a colourless oil. Yield $1.35 \mathrm{~g}(74 \%) .{ }^{1} \mathrm{H}$ NMR (benzene- $\left.d_{6}, 400.13 \mathrm{MHz}, 298 \mathrm{~K}\right): \delta 7.20-7.13$ (m, $\left.2 \mathrm{H}, m-\mathrm{C}_{6} H_{5}\right), 7.11-7.05\left(\mathrm{~m}, 1 \mathrm{H}, p-\mathrm{C}_{6} H_{5}\right), 7.00-6.95\left(\mathrm{~m}, 2 \mathrm{H}, o-\mathrm{C}_{6} H_{5}\right), 6.43(\mathrm{~s}, 1 \mathrm{H}, \mathrm{OH}), 3.00-$ 
1.72 (overlapping m, 7H, $\mathrm{CH}_{2} \mathrm{C}\left(\mathrm{CF}_{3}\right)_{2}, \mathrm{NCH}_{2} \mathrm{CH}_{2}, \mathrm{NCH}_{2} \mathrm{CH}_{2}$ and $\left.\mathrm{CH}\left(\mathrm{CH}_{3}\right)_{2}\right), 0.63\left(\mathrm{~d}, 6 \mathrm{H},{ }^{3} J_{\mathrm{H}-\mathrm{H}}\right.$ $\left.=6.5 \mathrm{~Hz}, \mathrm{CH}\left(\mathrm{CH}_{3}\right)_{2}\right) \mathrm{ppm} .{ }^{13} \mathrm{C}\left\{{ }^{1} \mathrm{H}\right\} \mathrm{NMR}$ (benzene- $\left.d_{6}, 125.77 \mathrm{MHz}, 298 \mathrm{~K}\right): \delta 139.10\left(i-C_{6} \mathrm{H}_{5}\right)$, $128.97\left(m-C_{6} \mathrm{H}_{5}\right), 128.86\left(o-C_{6} \mathrm{H}_{5}\right), 126.79\left(p-C_{6} \mathrm{H}_{5}\right), 124.51\left(\mathrm{q},{ }^{1} J_{\mathrm{C}-\mathrm{F}}=288.1 \mathrm{~Hz}, C \mathrm{~F}_{3}\right), 72.17$

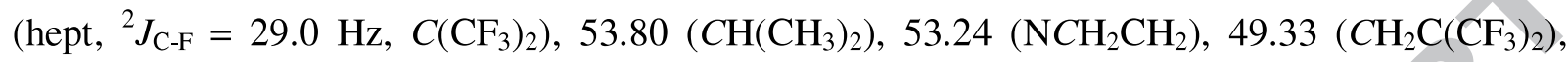
$35.50\left(\mathrm{NCH}_{2} \mathrm{CH}_{2}\right), 18.30\left(\mathrm{CH}\left(\mathrm{CH}_{3}\right)_{2}\right) \mathrm{ppm} .{ }^{19} \mathrm{~F}\left\{{ }^{1} \mathrm{H}\right\}$ NMR (benzene- $\left.d_{6}, 376.49 \mathrm{MHz}, 298 \mathrm{~K}\right): \delta-$ $77.16\left(\mathrm{~s}, 6 \mathrm{~F}, \mathrm{CF}_{3}\right)$ ppm. Elemental analysis for $\mathrm{C}_{15} \mathrm{H}_{19} \mathrm{~F}_{6} \mathrm{NO}\left(343.31 \mathrm{~g} \cdot \mathrm{mol}^{-1}\right)$ : calcd, $\mathrm{C} 52.5 \%, \mathrm{H}$ $5.6 \%, \mathrm{~N} 4.1 \%$; found $\mathrm{C} 53.1 \%, \mathrm{H} 5.2 \%, \mathrm{~N} 4.1 \%$. Mass spectrometry $\mathrm{ESI}\left[\mathrm{M}+\mathrm{Na}^{+}\right]$ $\left(\mathrm{C}_{15} \mathrm{H}_{19} \mathrm{NOF}_{6} \mathrm{Na}\right) \mathrm{m} / z$ calcd: 366.12685 ; found 366.1267 .

$\left[\mathrm{Ca}_{3}\left(\mu-\mathrm{N}\left(\mathrm{SiMe}_{2} \mathrm{H}\right)_{2}\right)_{2}\left(\mu-\mathrm{RO}^{\mathbf{l}}\right)_{2}\left(\boldsymbol{N}\left(\mathrm{SiMe}_{2} \mathrm{H}\right)_{2}\right)_{2}\right]$ (2). A solution of $\left\{\mathrm{RO}^{1}\right\} \mathrm{H}(92 \mathrm{mg}, 0.30 \mathrm{mmol})$ in diethyl ether $(10 \mathrm{~mL})$ was added at $-78{ }^{\circ} \mathrm{C}$ over a period of $1 \mathrm{~h}$ to a solution of $\left[\mathrm{Ca}\left[\mathrm{N}\left(\mathrm{SiMe}_{2} \mathrm{H}\right)_{2}\right]_{2} \bullet(\mathrm{THF})\right](170 \mathrm{mg}, 0.45 \mathrm{mmol})$ in diethyl ether $(10 \mathrm{~mL})$. The reaction mixture was warmed to room temperature and stirred for $1 \mathrm{~h}$. The volatiles were then removed under vacuum. The resulting oil was stripped with pentane $(3 \times 3 \mathrm{~mL})$ and dried under dynamic vacuum overnight. More stripping with pentane $(3 \times 3 \mathrm{~mL})$ is then required to afford the title compound as a colourless powder. Yield $128 \mathrm{mg}$ (68\%). Crystals suitable for X-ray diffractometry were obtained from a concentrated pentane solution stored at $-30{ }^{\circ} \mathrm{C}$. ${ }^{1} \mathrm{H}$ NMR (benzene- $d_{6}, 400.13 \mathrm{MHz}, 298 \mathrm{~K}$ ): $\delta 5.75-5.55\left(\mathrm{~m}, 2 \mathrm{H}, \mathrm{CH}=\mathrm{CH}_{2}\right.$ ), 5.18-4.94 (overlapping m, $9 \mathrm{H}, \mathrm{CH}=\mathrm{CH}_{2}$ and $\left.\mathrm{SiH}\right), 4.74(\mathrm{~s}, 2 \mathrm{H}, \mathrm{Si} H), 4.59(\mathrm{~s}, 1 \mathrm{H}, \mathrm{Si} H), 3.52-3.40\left(\mathrm{~m}, 2 \mathrm{H}, \mathrm{C}(H) \mathrm{HC}\left(\mathrm{CF}_{3}\right)\right.$, 3.08-2.71 (overlapping m, 4H, $\mathrm{C}(\mathrm{H}) H \mathrm{C}\left(\mathrm{CF}_{3}\right)_{2}$ and $\mathrm{NC}(\mathrm{H}) H \mathrm{HCH}_{2}$ ), 2.34-2.11 (overlapping $\mathrm{m}, 4 \mathrm{H}$, $\mathrm{NCH}_{2} \mathrm{C}(\mathrm{H}) H$ and $\left.\mathrm{NC}(H) \mathrm{HCH}_{2}\right), 2.07-1.86\left(\mathrm{~m}, 2 \mathrm{H}, \mathrm{NC}(\mathrm{H}) H \mathrm{CH}_{2}\right), 1.05\left(\mathrm{~s}, 18 \mathrm{H}, \mathrm{C}\left(\mathrm{CH}_{3}\right)_{3}\right), 0.55-$ 0.32 (overlapping m, $\mathrm{SiCH}_{3}, 48 \mathrm{H}$ ) ppm. ${ }^{13} \mathrm{C}\left\{{ }^{1} \mathrm{H}\right\}$ NMR (benzene- $d_{6}, 100.62 \mathrm{MHz}, 298 \mathrm{~K}$ ): $\delta$ $134.26\left(C \mathrm{H}=\mathrm{CH}_{2}\right), 128.59\left(\mathrm{q},{ }^{1} J_{\mathrm{CF}}=285.8 \mathrm{~Hz}, C \mathrm{~F}_{3}\right), 117.94\left(\mathrm{CH}=\mathrm{CH}_{2}\right), 79.58\left(\mathrm{br}, C\left(\mathrm{CF}_{3}\right)_{2}\right)$, $57.67\left(C\left(\mathrm{CH}_{3}\right)_{3}\right), 49.10\left(\mathrm{CH}_{2} \mathrm{C}\left(\mathrm{CF}_{3}\right)_{2}\right), 44.38\left(\mathrm{NCH}_{2} \mathrm{CH}_{2}\right), 29.00,\left(\mathrm{C}\left(\mathrm{CH}_{3}\right)_{3}\right), 28.03\left(\mathrm{NCH}_{2} \mathrm{CH}_{2}\right)$ 
5.14, 4.90, 4.51, 4.03, 3.73 (all $\mathrm{SiCH}_{3}$ ) ppm. ${ }^{19} \mathrm{~F}\left\{{ }^{1} \mathrm{H}\right\}$ NMR (benzene- $d_{6}, 376.44 \mathrm{MHz}, 298 \mathrm{~K}$ ): -78.15 (br s, 3F, $\mathrm{CF}$ ), -78.95 (br s, 3F, $\mathrm{C} F_{3}$ ) ppm. Satisfactory elemental analysis for $\mathrm{C}_{40} \mathrm{H}_{92} \mathrm{Ca}_{3} \mathrm{~F}_{12} \mathrm{~N}_{6} \mathrm{O}_{2} \mathrm{Si}_{8}$ (1262.11 g. $\mathrm{mol}^{-1}$; theoretical, C $38.1 \%$, H 7.3\%, N 6.7\%) could not be obtained despite repeated attempts, presumably owing to the air- and moisture-sensitivity of 2 .

$\left[\mathrm{Ca}_{3}\left(\mu-\mathrm{N}\left(\mathrm{SiMe}_{2} \mathrm{H}\right)_{2}\right)_{2}\left(\mu-\mathrm{RO}^{3}\right)_{2}\left(\mathrm{~N}\left(\mathrm{SiMe}_{2} \mathrm{H}\right)_{2}\right)_{2}\right](4)$. A solution of $\left\{\mathrm{RO}^{2}\right\} \mathrm{H}(0.11 \mathrm{~g}, 0.32 \mathrm{mmol})$ in $\mathrm{Et}_{2} \mathrm{O}(8 \mathrm{~mL})$ was added at $-78{ }^{\circ} \mathrm{C}$ over $1 \mathrm{~h}$ to a solution of $\left[\mathrm{Ca}\left[\mathrm{N}\left(\mathrm{SiMe}_{2} \mathrm{H}\right)_{2}\right]_{2} \cdot(\mathrm{THF})\right](150 \mathrm{mg}$, $0.41 \mathrm{mmol})$ in $\mathrm{Et}_{2} \mathrm{O}(7 \mathrm{~mL})$. The reaction mixture was warmed to room temperature and after stirring for $1 \mathrm{~h}$ the volatiles were removed in vacuo. The resulting oil was stripped with pentane $(3 \times 4 \mathrm{~mL})$ to give a colourless powder that was only partially soluble in pentane. Yield $129 \mathrm{mg}$ (71\% based on $\mathrm{Ca}$, assuming the isolated product is the title compound). ${ }^{1} \mathrm{H}$ and ${ }^{19} \mathrm{~F}$ NMR data recorded in benzene- $d_{6}$ only afforded very large, unassignable resonances. A small crop of single crystals of 4 were obtained from a concentrated pentane solution at $-4{ }^{\circ} \mathrm{C}$.

\subsubsection{X-ray diffraction crystallography}

X-ray diffraction data were collected at $150 \mathrm{~K}$ using a Bruker APEX CCD diffractometer with graphite-monochromated Mo K $\alpha$ radiation $(\lambda=0.71073 \AA$ ). A combination $\omega$ and $\Phi$ scans was carried out to obtain at least a unique data set. The crystal structures were solved by direct methods, and remaining atoms were located from difference Fourier synthesis followed by fullmatrix least-squares based on $F^{2}$ (programs SIR97 and SHELXL-97) [21]. The $\mathrm{Si} H$ atoms could be found from the Fourier difference analysis. Carbon-, oxygen-, and nitrogen- bound hydrogen atoms were placed at calculated positions and forced to ride on the attached atom. All nonhydrogen atoms were refined with anisotropic displacement parameters. The locations of the largest peaks in the final difference Fourier map calculation as well as the magnitude of the 
residual electron densities were of no chemical significance. A summary of crystallographic data for 2 (CCDC \# 1551126) and 4 (CCDC \# 1508555) is collected in Table 2.

Table 2.

Summary of crystallographic data for complexes $\mathbf{2}$ and $\mathbf{4}$.

$$
\begin{array}{cc}
{\left[\mathrm { Ca } _ { 3 } ( \mu ^ { 2 } - \{ \mathrm { RO } ^ { 1 } \} ) _ { 2 } \left(\mu^{2}-\right.\right.} & {\left[\mathrm { Ca } _ { 3 } ( \mu ^ { 2 } - \{ \mathrm { RO } ^ { 3 } \} ) _ { 2 } \left(\mu^{2}-\right.\right.} \\
\left.\left.\mathrm{N}\left(\mathrm{SiMe}_{2} \mathrm{H}\right)_{2}\right)_{2}\left(\mathrm{~N}\left(\mathrm{SiMe}_{2} \mathrm{H}\right)_{2}\right)_{2}\right] & \left.\left.\mathrm{N}\left(\mathrm{SiMe}_{2} \mathrm{H}\right)_{2}\right)_{2}\left(\mathrm{~N}\left(\mathrm{SiMe}_{2} \mathrm{H}\right)_{2}\right)_{2}\right]
\end{array}
$$

(2)

Formula
CCDC
Mol. wt.
Crystal system

C40H92Ca3F12N6O2Si8

1551126

1262.15

Orthorhombic

Space group

$$
\begin{aligned}
& A(\AA) \\
& B(\AA) \\
& C(\AA) \\
& \alpha\left(^{\circ}\right) \\
& \beta\left(^{\circ}\right) \\
& \gamma\left({ }^{\circ}\right) \\
& \mathrm{V}\left(\AA^{3}\right)
\end{aligned}
$$$$
Z
$$

Density $\left(\mathrm{g} / \mathrm{cm}^{3}\right)$

Abs. coeff., $\left(\mathrm{mm}^{-1}\right)$

$F(000)$

Crystal size, mm

$\theta$ range $\left(^{\circ}\right)$

Limiting indices

$R$ (int)

Reflections collected

Reflec. Unique $[I>2 \sigma(I)]$

Completeness to $\theta$

Data/restraints/param.

Goodness-of-fit

$R_{1}[I>2 \sigma(I)]$ (all data)

$\mathrm{w} R_{2}[I>2 \sigma(I)]$ (all data)
Aba2

14.0150(5)

27.1493(10)

17.7741(6)

90

90

90

6763.0(4)

1.240

0.454

2680

$0.36 \times 0.35 \times 0.30$

2.914 to 27.485

$-16<\mathrm{h}<18$

$-35<\mathrm{k}<35$

$-23<1<22$

0.0378

20740

7456

0.997

$7456 / 1 / 344$

1.010

$0.0291(0.0371)$

$0.0628(0.0662)$
(4)

C46H92Ca3F12N6O2Si8
1508555
1334.22

1334.22

Monoclinic

P $21 / n$

16.9389(14)

23.637(2)

18.2405(13)

90

106.491(5)

90

7002.7(10)

4

1.266

0.442

2824

$0.22 \times 0.13 \times 0.09$

2.96 to 27.48

$-17<\mathrm{h}<21$

$-30<\mathrm{k}<29$

$-23<1<23$

0.2026

51750

15935

0.992

15935 / 0 / 738

0.945

$0.0831(0.2834)$

$0.1438(0.2068)$ 


\section{Acknowledgements}

S.-C. R. thanks the French Agence Nationale de la Recherche for a $\mathrm{PhD}$ grant (GreenLAkE, ANR-11-BS07-009-01).

\section{References}

[1] (a) A. G. M. Barrett, M. R. Crimmin, M. S. Hill, P.A. Procopiou, Proc. R. Soc. A 466 (2010) 927-963;

(b) S. Harder, Chem. Rev. 110 (2010) 3852-3876;

(c) M. R. Crimmin, M. S. Hill, Top. Organomet. Chem. 45 (2013) 191-242;

(d) M. S. Hill, D. J. Liptrot, C. Weetman, Chem. Soc. Rev. 45 (2016) 972-988;

(e) Y. Sarazin, J.-F. Carpentier, Chem. Rec. 16 (2016) 2482-2505.

[2] (a) M. D. Anker, M. Arrowsmith, P. Bellham, M. S. Hill, G. Kociok-Köhn, D. J. Liptrot, M. F. Mahon, C. Weetman, Chem. Sci. 5 (2014) 2826-2830;

(b) D. J. Liptrot, M. Arrowsmith, A. L. Colebatch, T. J. Hadlington, M. S. Hill, G. KociokKöhn, M. F. Mahon, Angew. Chem. Int. Ed. 54 (2015) 15280-15283.

[3] (a) M. Westerhausen, Coord. Chem. Rev. 252 (2008) 1516-1531;

(b) A. Torvisco, K. Ruhlandt-Senge, Top. Organomet. Chem. 45 (2013) 1-28;

(c) M. Westerhausen, J. Langer, S. Krieck, R. Fischer, H. Görls, M. Köhler, Top. Organomet. Chem. 45 (2013) 29-72;

(d) For a recent review, see: M. Westerhausen, A. Koch, H. Görls, S. Krieck, Chem. Eur. J. 23 (2017) 1456-1483. 
[4] S. Krieck, H. Görls, L. Yu, M. Reiher, M. Westerhausen, J. Am. Chem. Soc. 131 (2009) 2977-2985.

[5] (a) M. S. Hill, P. B. Hitchcock, Chem. Commun. 2003, 1758-1759;

(b) A. G. Avent, M. R. Crimmin, M. S. Hill, P. B. Hitchcock, Dalton Trans. 2005, 278-284.

[6] See for instance:

(a) M. R. Crimmin, I. J. Casely, M. S. Hill, J. Am. Chem. Soc. 127 (2005) 2042-2043;

(b) M. R. Crimmin, M. Arrowsmith, A. G. M. Barrett, I. J. Casely, M. S. Hill, P. A. Procopiou, J. Am. Chem. Soc. 131 (2009), 9670-9685;

(c) A. G. M. Barrett, C. Brinkmann, M. R. Crimmin, M. S. Hill, P. Hunt, P. A. Procopiou, J. Am. Chem. Soc. 131 (2009) 12906-12907;

(d) C. Brinkmann, A. G. M. Barrett, M. S. Hill, P. A. Procopiou, J. Am. Chem. Soc. 134 (2012) 2193-2207.

[7] B. Liu, T. Roisnel, J.-F. Carpentier, Y. Sarazin, Angew. Chem. Int. Ed. 51 (2012) 49434946.

[8] B. Liu, T. Roisnel, J.-F. Carpentier, Y. Sarazin, Chem. Eur. J. 19 (2013) 2784-2802.

[9] S.-C. Roşca, T. Roisnel, V. Dorcet, J.-F. Carpentier, Y. Sarazin, Organometallics 33 (2014) $5630-5642$.

[10] W. D. Buchanan, D. G. Allis, K. Ruhlandt-Senge, Chem. Commun. 46 (2010) 4449-4465.

[11] Y. Sarazin, D. Roşca, V. Poirier, T. Roisnel, A. Silvestru, L. Maron, J.-F. Carpentier, Organometallics 29 (2010) 6569-6577.

[12] Y. Sarazin, B. Liu, T. Roisnel, L. Maron, J.-F. Carpentier, J. Am. Chem. Soc. 133 (2011) 9069-9087. 
[13] (a) S.-C. Roşca, C. Dinoi, E. Caytan, V. Dorcet, M. Etienne, J.-F. Carpentier, Y. Sarazin, Chem. Eur. J. 22 (2016) 6505-6509;

(b) S.-C. Roşca, E. Caytan, V. Dorcet, T. Roisnel, J.-F. Carpentier, Y. Sarazin, Organometallics 36 (2017) 1269-1277.

[14] O. Michel, K. W. Törnroos, C. Maichle-Mössmer, R. Anwander, Chem. Eur. J. 17 (2011) 4964-4967.

[15] H. Plenio, Chem. Rev. 97 (1997) 3363-3384.

[16] S.-C. Roşca, D.-A. Roşca, V. Dorcet, C. M. Kozak, F. M. Kerton, J.-F. Carpentier, Y. Sarazin, Dalton Trans. 42 (2013) 9361-9375.

[17] I. D. Brown, D. Altermatt, Acta Crystallogr. Sect. B B41 (1985) 244-247.

[18] N. E. Brese, M. O’Keefe, Acta Crystallogr. Sect. B B47 (1991) 192-197.

[19] (a) W. D. Buchanan, E. D. Nagle, K. Ruhlandt-Senge, Main Group Chem. 8 (2009), 263-273;

(b) J. S. Sum, L. Tahsini, J. A. Golen, C. Moore, A. L. Rheingold, L. H. Doerrer, Chem. Eur. J. 19 (2013) 6374-6384;

(c) W. D. Buchanan, K. Ruhlandt-Senge, Chem. Eur. J. 19 (2013) 10708-10715.

[20] (a) J. Hitzbleck, A. Y. O'Brien, G. B. Deacon, K. Ruhlandt-Senge, Inorg. Chem. 45 (2006) 10329-10337;

(b) A. Torvisco, K. Decker, F. Uhlig, K. Ruhlandt-Senge, Inorg. Chem. 48 (2009) 1145911465;

(c) J. F. Kögel, L. H. Finger, N. Frank, J. Sundermeyer, Inorg. Chem. 53 (2014) 3839-3846; 
(d) P. Bellham, M. D. Anker, M. S. Hill, G. Kociok-Köhn, M. F. Mahon, Dalton Trans. 45 (2016) 13969-13978;

(e) S.-C. Roşca, H. Roueindeji, V. Dorcet, T. Roisnel, J.-F. Carpentier, Y. Sarazin, Inorganics (2017), DOI: 10.3390/inorganics5010013.

[21] (a) Sheldrick, G. M. SHELXS-97, Program for the Determination of Crystal Structures; University of Goettingen: Germany, 1997;

(b) Sheldrick, G.M. SHELXL-97, Program for the Refinement of Crystal Structures; University of Goettingen: Germany, 1997. 
Graphical abstract for

Secondary Interactions - Cement in Trinuclear Calcium Complexes

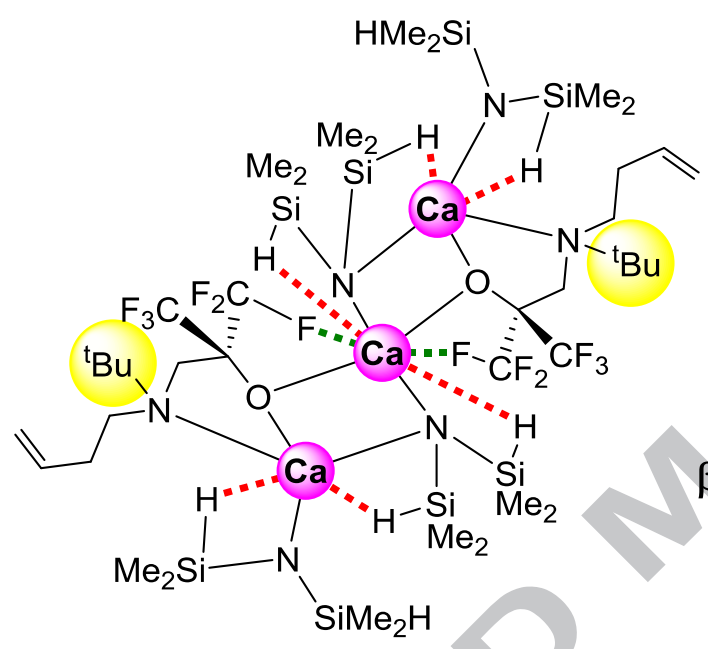

Secondary interactions

in calcium chemistry

Intramolecular $\mathrm{Ca} \ldots \mathrm{F}$ and

$\beta$-agostic $\mathrm{Ca} \ldots \mathrm{H}-\mathrm{Si}$ interactions

hold it together! 
Highlights for

Secondary Interactions - Cement in Trinuclear Calcium Complexes

- An original trinuclear, soluble calcium fluoroalkoxide is presented

- Detailed structural analysis is provided

- This complex is held together by $\beta-\mathrm{Si}-\mathrm{H} \cdots \mathrm{Ca}$ agostic and $\mathrm{C}-\mathrm{F} \cdots \mathrm{Ca}$ interactions

- The contributions of these interactions are gauged by bond valence sum analysis 